\title{
A MODEL OF LEAN MANAGEMENT FOR ORGANIZATIONAL INNOVATION: CASES IN VISEGRÁD AND AFTA
}

doi: $\quad 10.2478 /$ czoto-2019-0068

Date of submission of the article to the Editor: $15 / 11 / 2018$

Date of acceptance of the article by the Editor: 28/12/2018

Tuan-anh $\operatorname{Tran}^{1}$ - orcid id: 0000-0002-3098-7075

Rajab Ghabour ${ }^{1}$

My Nguyen ${ }^{2}$

Miklós Daróczi ${ }^{1}$

${ }^{1}$ Szent Istvan University, Hungary, ghabour.rajab@hallgato.uni-szie.hu

${ }^{2}$ Vietnam Maritime University, Vietnam

Abstract: Originated as a production management philosophy, Lean Manufacturing has successfully transferred and implemented globally. Lean genealogy studies have been conducted, indicating the essential concept now evolves to Lean Management (LM), which is applicable to many branches of production and services management, viz quality and productivity, human resources, knowledge and technology, etc. Innovation has been made to ensure a smooth customization of knowledge and principles, tailored to each organization who is eager to implement this state-of-the-art management system. However, failures are becoming commonplace due to the lack of understanding the core values, and insufficient intensification of compensation for cultural differences. In this paper, cases of implementing LM across the Visegrád group (V4) and the ASEAN Free Trade Area (AFTA) from previous literature are taken into consideration. Factors that differentiate the characteristic of LM are brought to discussion. Therefore, the discovered gap between the two trade blocs urges the indepth amendment and modification of employed concepts, tools, etc. A model is consequently elaborated, which aims at facilitate the managerial decision-making process regarding knowledge transfer of LM between V4 and AFTA, based on critical factors related to human, technology and culture, i.e. Labor cost, Manual requirement, Awareness, Continuous Improvement culture. This model can be used to predict the change should be made, or the criterion should be fulfilled to transfer the implementation and knowledge of LM effectively.

Keywords: Lean management, Organizational Innovation, Knowledge transfer, V4, AFTA.

\section{INTRODUCTION}

LM has long been discussed in many researches and applied in the production process of enterprises as an effective tool for organizational changes thanks to waste minimization. Conceptualized by Womack, Jones and Roos (1992), then re-confirmed 
the importance of Value and Flow in Lean thinking for the whole operation of an organization. The idea of Lean in Product Development process is introduced by Rauch, Dallasega and Matt (2017), and the use of Lean for Software Product Innovation is mentioned by Edison et al. (2018). Although the vital role of Lean has widely been accepted as pointing out and cutting down wastes during a value chain of a company, the clear boundary of this concept is still controversy through different industries and regions. However, the variation of Lean application convergence into one common purpose: improve the "Leanness" level. The Leanness of a Lean-adopted company is depicted in many literatures as the success level of a company in implementing and sustaining the Lean philosophy in its manufacturing system, as depicted in (Table 1).

Table 1

Leanness concepts and approaches through literature reviews

\begin{tabular}{|c|c|}
\hline Authors & Findings \\
\hline Bayou and de Korvin, 2008 & $\begin{array}{l}\text { Leanness as a strategy to incur less input to better achieve } \\
\text { organizational goals by producing higher - quality output }\end{array}$ \\
\hline $\begin{array}{l}\text { Vlachos and Bogdanovic, } \\
2013\end{array}$ & Leanness as the operation flows \\
\hline Ante et al., 2018 & $\begin{array}{l}\text { Company leanness is measured through KPI to examine } \\
\text { organizational operators' qualifications to perform with } \\
\text { machines }\end{array}$ \\
\hline Al-Aomar, 2011 & $\begin{array}{l}\text { Firms achieve leanness by WIP level, controlling lead time and } \\
\text { job - per - hour productivity }\end{array}$ \\
\hline $\begin{array}{l}\text { Wahab, Mukhtar and } \\
\text { Sulaiman, } 2013\end{array}$ & $\begin{array}{l}\text { Develop a model to measure } 7 \text { LM dimensions: Manufacturing } \\
\text { Processes \& Equipment, Manufacturing Planning \& } \\
\text { Scheduling, Visual Information System, Product Development } \\
\text { \& Technology, Workforce Management, Supplier Relationship, } \\
\text { Customer Relationship }\end{array}$ \\
\hline Bhasin, 2011 & $\begin{array}{l}\text { Define company's leanness through } 10 \text { categories: Overall } \\
\text { safety and cleanliness; Visual Management; Incorporated } \\
\text { Design for Quality; Continuous Improvement; Lean change } \\
\text { strategy; Lean sustainability; Culture-employee oriented; } \\
\text { Organizational culture; Lean business and Lean philosophy }\end{array}$ \\
\hline Alemi and Akram, 2013 & $\begin{array}{l}\text { Leanness is considered through } 11 \text { categories: Visual } \\
\text { management system; Management of complexity and } \\
\text { variability; Customer satisfaction; Supply chain integration; } \\
\text { Safety, environment, cleanliness, and order; Use of space, } \\
\text { movement of materials, and product line flow; Commitment to } \\
\text { quality; Teamwork and motivation; Levels of inventory and } \\
\text { work in process; Scheduling system }\end{array}$ \\
\hline $\begin{array}{l}\text { Vlachos and Bogdanovic, } \\
2013\end{array}$ & Leanness as the operation flows \\
\hline
\end{tabular}

Source: own study

V4 and AFTA have been experiencing harsh competitiveness within their own area courtesy of intra-regional free trade. V4 countries, even though ended their membership among the Central European Free Trade Agreement (CEFTA) right after joining EU to enjoy their bigger free trade benefits in the world's largest common market, are still finding solutions for better positions in the Union, as they gain less 
competitive advantages compared to other EU nations in terms of poor knowledge of tools and methodologies for organizational innovations. Regarding their Southeast Asian peers' efforts to mark names on the international free trade map, there have been, though, some tried to cut down on production wastes to gain more business productivity and increase revenues, can all be seen as little efforts.

Therefore, continuous innovation for knowledge transfer is particularly important among countries, leading to the fact that many companies and organizations in not only V4 but also in the AFTA have been looking for ways to applying Lean tools and models to gain improvements in Quality, Cost, and Delivery metrics.

In this paper, a model reflects the Lean operation for a manufacturing or service enterprise is developed, also its Leanness is proposed to be affected by four factors: Labor cost, Awareness of personnel, Manual requirement level, Continuous Improvement $(\mathrm{Cl})$ culture. Since the paper's main focus lays on the implementation of Lean in manufacturing and some service systems of organizations, there might be some differences among manufacturing enterprises and services companies such as healthcare, airline, logistics, transportation, educational fields, etc.

\section{METHODOLOGY OF RESEARCH}

The research is based on thorough literature review, to generalize and compare the cases of LM implementation in V4 and AFTA. Through comparing the variation of Lean application in these countries, a Lean "trend" can be depicted. A model is generated based on four factors which affect the success of the result, four hypotheses are elaborated.

\section{IMPACT FACTORS OF LEAN MANAGEMENT IN V4 AND AFTA}

\subsection{Labor cost}

This factor has been subjected to many previous studies, as one of the main urging forces for the need of Lean: to cut down the production cost. A trend can be observed, as in cheap-labor region e.g. Vietnam, Malaysia in particular, AFTA in general, the usage of workforce can be intensive and overloaded. This can be considered as a burden to Lean, since the waste in human intellectual is neglected easily. Some companies even use unqualified human-resources for production process, in order to cut down the production price, thus leads to the difficulty of LM employment (Widiasih, Karningsih and Ciptomulyono, 2015).

In construction industry in Malaysia, the cheap cost of employment is reported as an encouraging factor for labor-intensive usage production method than innovative ones, creating more waste (CIDB MALAYSIA, 2008; Marhani, Jaapar and Bari, 2012). In Singapore, labor wages have experienced a modesty raise from 2012-2016, thus Lean has a higher implementation rate, SME's companies surveyed assisted their success of managing shorter lead times, lower prices for warehouse and goods unloading (Zhang et al., 2016).

In V4, however, the labor price is higher, that the urge to cut down waste from competitive market is more severe (Greskovits, 2006). At the same time, it is also noted that the level of employment rose to near the levels of the European Union. A new problem is shown which is the lack of employment. As many skilled workers travel to Western Europe for higher wages. For companies owned by foreign characters (A Strategic Framework for The Visegrad Group's Economic Cooperation, 2018), they are dependent on foreign economic actors. It is noted that the reliance of 
these countries on foreign investments does not result in enhancing wage-related goals.

\subsection{Awareness}

Awareness and knowledge are always important factors in Lean, since they involve personnel of company into real-life practice. This fact has been true for both AFTA and V4, and in the global ground in general. However; there are some sophisticated differences between these two blocs. As it can be considered, enterprises and researchers in AFTA put more emphasis on the awareness of personnel in the mental preparation for change, then any modification towards manufacturing systems can be done later. Meanwhile, the others in V4 focus more on prepare the logical thinking of workforce, what is the right sequence, the right method, root cause, etc.

The most frequent reason for a project failure is the inability to deliver LM training material/knowledge to the employees, with the lack of a growth mindset (Widiasih, Karningsih and Ciptomulyono, 2015; Minh and Ha, 2016; Pearce, Pons and Neitzert, 2018). The lack of communication for knowledge and information can lead to the result that employee cannot feel the benefit directly of implementing $L M$, thus undermined personnel commitment, or lead to misunderstanding (Wong, Wong and Ali, 2009), (Lila, 2012) report the situation in Thailand automotive industry, that the level of understanding lean concepts positively depends on the education and experience of key employees. (Pham, Le and Tran, 2018) suggested that in some Vietnamese SMEs, awareness plays a huge role in the successful application of lean management as well as enhancing the capacity for innovation.

In V4, the hotel industry is mainly a customer-focused industry. By reducing the proportion of waste and defects in the products, and most empirical studies do not focus on the human resources issue in transition. Therefore, researchers have conducted many researches on lean implementation within HR practices. Few studies have taken into consideration workers' feelings and perceptions, and no one has taken the employee's sense of success as a key guide to lean implementation. In addition, applying some tools may not led to the same result of other tool and this is may be due to lack of culture of change and lack of solid foundation to build the system lean and the intention of continuous improvement (Wyrwicka and Mrugalska, 2017).

\subsection{Manpower requirement}

Manual requirement level of production/service can be regarded as the manual added value ratio to the price of the product/service, by human labor. This factor is strongly influenced by the automation level, as in close connection with the type of industry (e.g. textile, leather industries have higher manual requirement value than conventional mechanical manufacturing industry, service industry cannot neglect the human labor, though the existence of communication technology). According to the previous cases, the manual requirement level can affect the choice of LM tools and concepts to be deployed. A categorization is detected in AFTA and V4 for different industry, which is listed in (Table 2) below. In AFTA, the margin for abovementioned categorization is relatively clear, while in V4 is blurred. Since the SMEs in V4 mainly had to implement the production system in compliance with their larger corporations, which sometime is incompatible to regional and national trends. 
Table 2.

Categorization of LM tools and concepts due to the manual requirement

\begin{tabular}{|c|c|c|}
\hline Manual requirement level & LM concepts and tools & References \\
\hline $\begin{array}{l}\text { Low manual requirement } \\
\text { (high automation level), } \\
\text { e.g. Food processing, } \\
\text { Distillation, Brewing, } \\
\text { Chemical production, etc. }\end{array}$ & $\begin{array}{l}\text { Heijunka, Andon, Poka-Yoke, } \\
\text { Single-Minute-Exchange-of-Die } \\
\text { (SMED), Just in Time, TPM, takt- } \\
\text { time, Fault-detecting, Fool- } \\
\text { proofing, In Station Quality, } \\
\text { Process flexibility } \\
\text { (which aim at machine utilization) }\end{array}$ & $\begin{array}{l}\text { Tran et al., } 2016, \\
\text { Haragovics and Mizsey, } \\
2014\end{array}$ \\
\hline $\begin{array}{l}\text { Medium manual } \\
\text { requirement, e.g. } \\
\text { Mechanical manufacturing, } \\
\text { Assembling, Hotel service, } \\
\text { Automotive industry, etc. }\end{array}$ & $\begin{array}{l}\text { Standardized work (SW), Line- } \\
\text { Balancing, SMED, Process } \\
\text { Activity Mapping, Value Stream } \\
\text { Mapping, Pull system, } \\
\text { Continuous Improvement }\end{array}$ & $\begin{array}{l}\text { Tran et al., 2016, } \\
\text { Vlachos and } \\
\text { Bogdanovic, 2013, } \\
\text { Antosz and Stadnicka, } \\
2017\end{array}$ \\
\hline $\begin{array}{l}\text { High manual requirement } \\
\text { (low automation level), e.g. } \\
\text { Furniture manufacturing, } \\
\text { Textile, Leather, Sheet } \\
\text { metal stamping, etc. }\end{array}$ & $\begin{array}{l}\text { SW, Line-Balancing, One-piece- } \\
\text { flow, Poka-Yoke, FIFO, JIT, } \\
\text { Kanban, QCC, TQM, Time \& } \\
\text { Motion study } \\
\text { (which aim at labor utilization) }\end{array}$ & $\begin{array}{l}\text { Le, Do and Nam, 2010, } \\
\text { Choomlucksana, } \\
\text { Ongsaranakorn and } \\
\text { Suksabai, 2015, Nguyen } \\
\text { and Do, 2016; Nguyen } \\
\text { Thi et al., 2016 }\end{array}$ \\
\hline
\end{tabular}

Source: own study

\subsection{Continuous Improvement culture}

$\mathrm{Cl}$ culture has varied definitions geographically, assumed by the Eastern culture as the willing to change, and expected to be Life-long-learning attitude in the Western culture. Despite the variation, researchers agreed that this factor is the most important factor to maintain the Lean KPI (Wong, Y.C.; Wong, K.Y. and Ali, 2009; Vlachos and Bogdanovic, 2013; Widiasih, Karningsih and Ciptomulyono, 2015). Even with a simple tool such as 5S, if the company cannot maintain the result, the effective of the whole Lean program will reduced, and the employee become afraid of $\mathrm{Cl}$ and conducting other Lean tools (Minh and $\mathrm{Ha}, 2016$ ). The $\mathrm{Cl}$ culture of a company is believed to be influenced by its embedded culture, from organizational level, from the nature of the workforce, or from the located country:

- From organizational level: It is easier for companies within a corporation which already has a $\mathrm{Cl}$ culture to learn the lessons. Commitment from leaders and organizational roadmap in a systematic way will ensure more success (Pham, Le and Tran, 2018). It also comes with a need of an organizational reward and recognizing system, as a pressure need to be maintained (Garza-Reyes et al., 2018), (Marhani, Jaapar and Bari, 2012; Widiasih, Karningsih and Ciptomulyono, 2015). A change management should be taken (Nordin, Md Deros and Abd Wahab, 2010). Otherwise, even a professional workforce cannot strive for Lean constantly (Jamil and Fathi, 2016).

- From the nature of workforce: Male workers in welding plant are influenced by the commitment and the logical way of working, while female workers in sewing factory are influenced specifically by beliefs and communication (Kull et al., 2014).

- From located country: Countries with high assertiveness tend to reduces the effectiveness of LM. In that case, Individual initiatives and personal judgement 
conflicts with the nature of LM (Kull et al., 2014). This effect can come from the strategy of the government, as they support the change and encouraging improvements (Svobodová and Hedvičáková, 2015).

Regarding the condition to maintain the $\mathrm{Cl}$ culture, there is a need of the long-term commitment from leaders, as well as their participation, which can encourage and motivate the employees (Losonci, Demeter and Jenei, 2011).

\section{SUGGESTED MODEL}

By discussing all the related factor with some literature reviews above, the authors present a model as illustrated in (Fig. 1) below. These four abovementioned factors are hypothesized to have effect on the Leanness, or in another words, a good LeanKPI set of a company. The foundation of a fruitful model of Leanness, are the manager's commitment, the principle of people involvement, and the support from technical team.

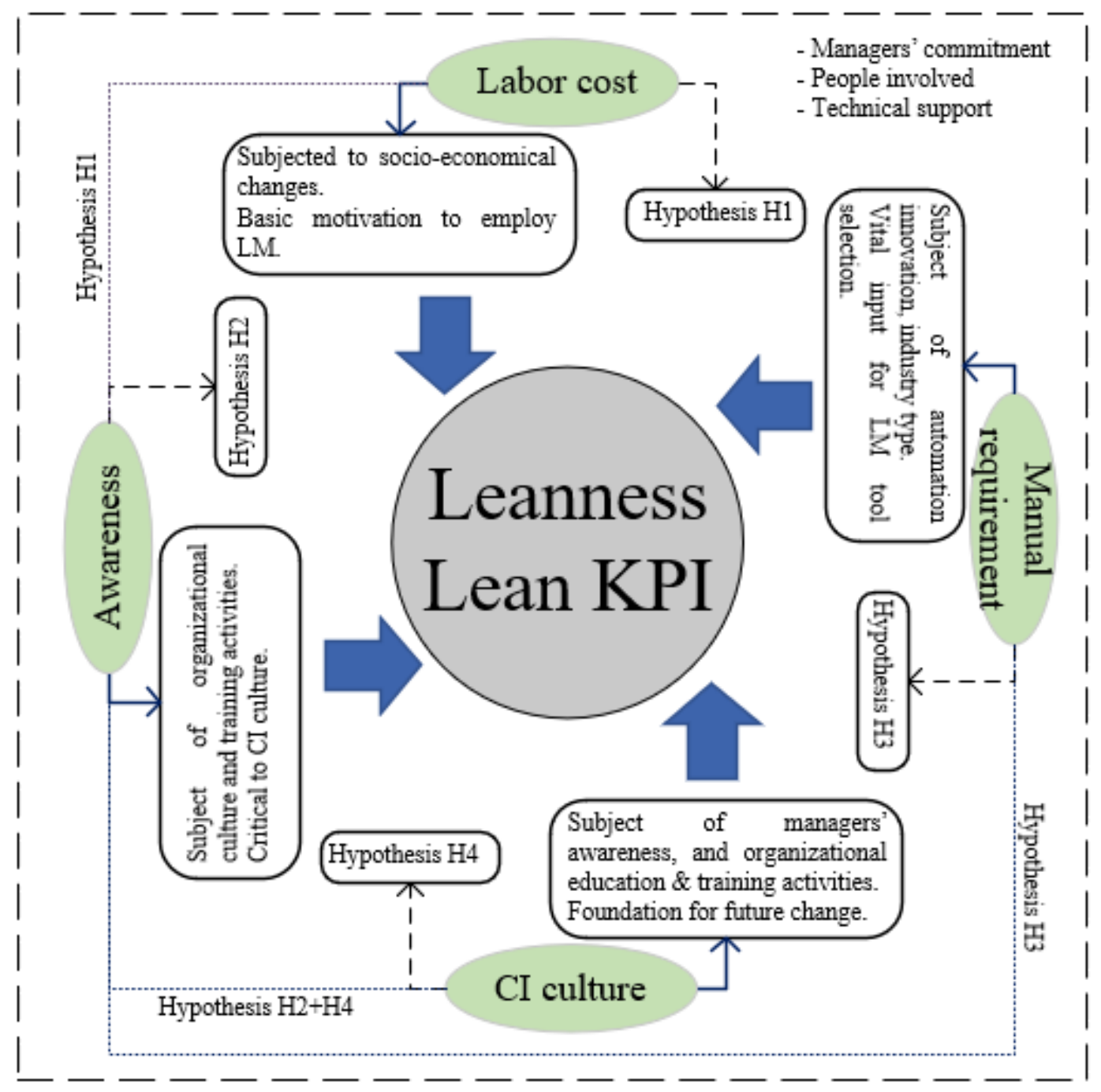

Fig. 1. The model of Leanness with four effected factors.

Based on the elaborated theoretical model, 4 hypotheses $(\mathrm{H} 1-\mathrm{H} 4)$ are developed.

H1: The increment of labor cost will affect the Leanness by urging the need for Lean: The goal of higher utilization of worker will have a priority in the manufacturing 
operation. If the labor cost is high, then the waste sources of Waiting, Overprocessing, Over-production should be ultimately focused. There will be a need for tools and training related to eliminate these kinds of wastes, with more considerably sophisticated tools related to employee-utilization, employee multi-skilled development. If the labor cost is low or reduced, there will be a chance that managers neglect the workers' efficiency, hence lead to more wastes can caused. The Lean projects will be harder to employ, consider the labor-cost saving is relatively lower.

H2: The level of lean knowledge and understanding being widely spread among employees in an organization could be a good base for Lean implementation to be applied in all organizational departments. If a company already has a good awareness, tools such as Group problem solving, Cross-functional team, Daily meeting can help to transfer and generate knowledge inside the workforce, educate the junior worker by the experienced ones.

On the contrary, the awareness of Lean is limited in an organization means it might be challenging for Lean projects to be utilized. There might be two cases to consider. Firstly, at the time when new employees are hired on, staff's knowledge about Lean could be narrow, encouraging managers to apply trainings about waste minimizing and Lean tools. Another scenario should be taken eyes on is the fact that employees continuously present their negative mindsets towards Lean, such employees should try to adapt and accept Lean transformations, since there is definitely no case that the whole organization cannot be leaner just due to some exceptional staff.

H3: For companies and industries with higher manual requirement, the multi-skilled and high-qualified workers will be more valuable than in the case of fully automated manufacturing. The more intensive usage of worker, the more need for tools and principles related to balance the task time of each worker, aim at an ultimate takt-time of the line. The use of multi-skilled labor, skill matrix employment could help educating the workers continuously.

However, if a company wants to invest to automation, or maintain a high level of automated engineering, Lean tools to utilize process flow, and make a smooth value stream within the production progress should be taken into consideration. However, the higher the automation, the less certified and high-skilled workers are in need. This will lead to the difficulty of conveying the Lean thinking and knowledge to the workforce, ultimately lead to the failure of Lean projects.

H4: The continuous improvement culture is deployed from the leaders themselves who create a working environment where achieving incremental achievements with sustainment is considered to be a key objective. This will allow for a culture that understands the value of sacrificing short term gains for long term benefits, allowing spaces for Lean tools application.

However, once the managers cannot establish an overall mindset for all staff about the importance of continuous improvements in an organization in order to cut down waste and gain productivity and organizational revenues, employees will not get enough knowledge of the importance of continuous change, leading to the failure of applying Lean tools and techniques into the operations of organizations.

\section{CONCLUSION AND DISCUSSION}

Visegrad group and AFTA share some common and contradictory aspects in the implementation and success of LM. Based on their differences in socio/human- 
factors, the Leanness of company in a specific industry is subjected to different advantages and disadvantages.

This paper hypothesized the Leanness of a Lean company within these two blocs is affected by four factors: Labor cost, Manual requirement level, Awareness of workers, and Continuous Improvement culture. A model is proposed, which discussed the importance, contribution, and effect of these factors on the managerial decision making process to ensure better organizational innovation. Related hypotheses are given, take into consideration these effects and future impact on the Leanness, if one of the factors is changed. Assumed-effective tools, which strongly dependent on the impact of each factor to the overall Leanness, are suggested to aim at a higher efficiency of LM implementation.

The model proposed can be a good base for organizations in the two regions to apply and perform Lean tools in the future when trade liberalization is becoming worldwide and might cause more complexities during countries' trading activities. However, further work needs to be taken to validate the model with its assumptions.

\section{REFERENCES}

Al-Aomar, R., 2011. Handling multi-lean measures with simulation and simulated annealing. Journal of the Franklin Institute, 348(7), 506-1522, doi: 10.1016/j.jfranklin.2010.05.002.

Alemi, M.A. and Akram, R., 2013. Measuring the leanness of manufacturing systems by using fuzzy topsis: a case study of the "parizan sanat" company. South African Journal of Industrial Engineering, 24(3), 166-174.

Ante, G. et al., 2018. Developing a key performance indicators tree for lean and smart production systems. IFAC-PapersOnLine, 51(11), 13-18, do: 10.1016/J.IFACOL.2018.08.227.

Antosz, K. and Stadnicka, D., 2017. Lean Philosophy Implementation in SMEs - Study Results. Procedia Engineering, 182, 25-32, doi: 10.1016/j.proeng.2017.03.107.

Bayou, M.E., de Korvin, A., 2008. Measuring the leanness of manufacturing systemsA case study of Ford Motor Company and General Motors. Journal of Engineering and Technology Management - JET-M, 25(4), 287-304, doi: 10.1016/j.jengtecman.2008.10.003.

Bhasin, S., 2011. Measuring the Leanness of an organisation. International Journal of Lean Six Sigma, 2(1), 56-74, doi: http://dx.doi.org/10.1108/MRR-09-2015-0216.

Choomlucksana, J., Ongsaranakorn, M., Suksabai, P., 2015. Improving the Productivity of Sheet Metal Stamping Subassembly Area Using the Application of Lean Manufacturing Principles. Procedia Manufacturing, 2(February), 102-107, doi: 10.1016/j.promfg.2015.07.090.

CIDB MALAYSIA, 2008. Malaysia Report. The 14th Asia Construct Conference, 1, 13-26.

Edison, H. et al., 2018. Lean Internal Startups for Software Product Innovation in Large Companies: Enablers and Inhibitors. Journal of Systems and Software, 135, 69-87, doi: 10.1016/j.jss.2017.09.034.

Garza-Reyes, J.A. et al., 2018. Lean Manufacturing Adoption in the Transport and Logistics Sector of Thailand - An Exploratory Study. Proceedings of the International Conference on Industrial Engineering and Operations Management, 1-12.

Haragovics, M., Mizsey, P., 2014. A novel application of exergy analysis: Lean manufacturing tool to improve energy efficiency and flexibility of hydrocarbon 
processing. Energy, 77, 82-390, doi: 10.1016/j.energy.2014.09.011.

Jamil, A.H.A. and Fathi, M.S., 2016. The Integration of Lean Construction and Sustainable Construction: A Stakeholder Perspective in Analyzing Sustainable Lean Construction Strategies in Malaysia. Procedia Computer Science, 100, 634-643, doi: 10.1016/j.procs.2016.09.205.

Kull, T.J. et al., 2014. The moderation of lean manufacturing effectiveness by dimensions of national culture: Testing practice-culture congruence hypotheses. International Journal of Production Economics. 153, 1-12, doi: 10.1016/j.jpe.2014.03.015.

Le, Q.-L. N., Do, N.-H., Nam, K.-C., 2010. Modeling and simulation of a lean system. case study of a paint line in a furniture company. Management Research and Practice, 2(3), 284-298.

Losonci, D., Demeter, K., Jenei, I., 2011. Factors influencing employee perceptions in lean transformations. International Journal of Production Economics, 131(1), 30-43, doi: 10.1016/j.jpe.2010.12.022.

Marhani, M.A., Jaapar, A., Bari, N.A.A., 2012. Lean Construction: Towards Enhancing Sustainable Construction in Malaysia. Procedia - Social and Behavioral Sciences, 68, 87-98, doi: 10.1016/j.sbspro.2012.12.209.

Minh, N.D., Ha, N.T.Van, 2016. "Made in Vietnam" Lean Management Model for Sustainable Development of Vietnamese Enterprises, 40, 603-608, doi: 10.1016/j.procir.2016.01.141.

Nguyen, M.N., Do, N.H., 2016. Re-engineering Assembly Line with Lean Techniques. Procedia CIRP, 40, 591-596, doi: 10.1016/j.procir.2016.01.139.

Nguyen Thi, L. et al., 2016. Lean Line Balancing for an Electronics Assembly Line, Procedia CIRP, 40(1), 437-442, doi: 10.1016/j.procir.2016.01.089.

Nordin, N., Md Deros, B., Abd Wahab, D., 2010. A Survey on Lean Manufacturing Implementation in Malaysian Automotive Industry. International Journal of Innovation, Management and Technology, 1(4), 374-380.

Pearce, A., Pons, D., Neitzert, T., 2018. Implementing lean-Outcomes from SME case studies. Operations Research Perspectives, 5, 94-104, doi: 10.1016/j.orp.2018.02.002.

Pham, H., Le, M., Tran, D., 2018. Kinh nghiệm quốc tế về kết hợp triển khai quản trị tinh gọn và thúc đẩy đổi mới sáng tạo. External Economics Review, 103.

Rauch, E., Dallasega, P., Matt, D.T. 2017. Critical Factors for Introducing Lean Product Development to Small and Medium sized Enterprises in Italy. Procedia CIRP. 60, 362-367, doi: 10.1016/j.procir.2017.01.031.

Svobodová, L., Hedvičáková, M., 2015. Doing Business in the Countries of Visegrad Group. Procedia Economics and Finance, 34(15), 453-460, doi: 10.1016/S22125671(15)01654-8.

Tran, T. et al., 2016. Lean manufacturing implementation in Vietnam: A flexible approach. Maritime Science and Technology Magazine, 48, 73-77.

Vlachos, I., Bogdanovic, A., 2013. Lean thinking in the European hotel industry, Tourism Management, 36, 354-363, doi: 10.1016/j.tourman.2012.10.007.

Wahab, A.N.A., Mukhtar, M., Sulaiman, R. 2013. A Conceptual Model of Lean Manufacturing Dimensions. Procedia Technology, 11(Iceei), 1292-1298, doi: 10.1016/j.protcy.2013.12.327.

Widiasih, W., Karningsih, P. D., Ciptomulyono, U., 2015. Development of Integrated Model for Managing Risk in Lean Manufacturing Implementation: A Case Study in an 
Indonesian Manufacturing Company. Procedia Manufacturing, 4(Lm), 282-290, doi: 10.1016/j.promfg.2015.11.042.

Womack, J. P., Jones, D. T., Roos, D., 1992. The machine that changed the world. Business Horizons, 35(3), 81-82, doi: 10.1016/0007-6813(92)90074-J.

Wong, Y.C., Wong, K.Y., Ali, A., 2009. A study on lean manufacturing implementation in the Malaysian electrical and electronics industry. European Journal of Scientific Research, 38(4), 521-535, doi: 10.1109/IACSIT-SC.2009.44.

Zhang, A. et al., 2016. Lean and Six Sigma in logistics: a pilot survey study in Singapore. International Journal of Operations and Production Management, 36(11), 1625-1643, doi: 10.1108/IJOPM-02-2015-0093. 